International Journal of Life Sciences
Available online at http://sciencescholar.us/journal/index.php/ijls
Vol. 2 No. 3, December 2018, pages: 48 58
e-ISSN: 2550-6986, p-ISSN: 2550-6994
https://doi.org/10.29332/ijls.v2n3.206

\title{
Efforts to Produce Siamese Citrus Fruit Out of Season and Fruit Quality Improvement through Application of Potassium Nitrate and Agrodyke Fertilizer
}

\author{
D CrossMark \\ Ni Komang Alit Astiari a , Luh Kartini b , Ni Putu Anom Sulistiawati c, I Nyoman Rai d \\ Article history: Received 25 July 2018, Accepted: 30 August 2018, Published: 12 October 2018
}

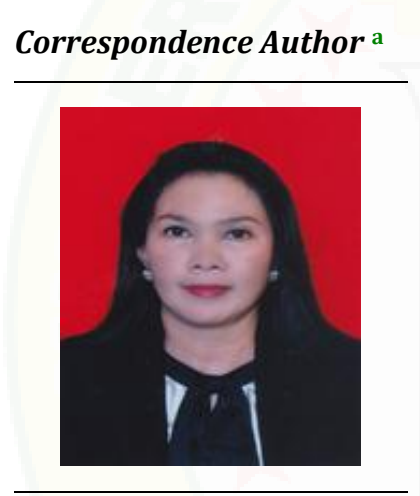

Keywords

Efforts to produce siamese citrus;

Fruit out season;

Fruit quality

improvement;

Potassium nitrate

application;

Agrodyke fertilizer;

\section{Abstract}

The research aimed to find out the efforts to produce off-season orange fruit and increase the quality of fruit through the application of potassium nitrate and agrodyke organic fertilizer. The study used a factorial randomized block design with 2 treatment factors. The first factor is the flower induction application using potassium nitrate $(\mathrm{K})$ consisting of 3 levels, namely (K0 $=0$ $\mathrm{g} /$ tree), ( $\mathrm{K} 1=20 \mathrm{~g} /$ tree), and ( $\mathrm{K} 2=40 \mathrm{~g} /$ tree $)$. While the second factor is the application of agrodyke organic fertilizer (P) consisting of 4 levels, namely (P0 $=0 \mathrm{~g} /$ tree), $(\mathrm{P} 1=15 \mathrm{~g} /$ tree $),(\mathrm{P} 2=30 \mathrm{~g} /$ tree $)$ and $(\mathrm{P} 3=45 \mathrm{~g} /$ tree $)$. There are 12 combination treatments and each of them is repeated 3 times so that 36 tree plants are needed. The results showed the interaction between potassium nitrate treatment with agrodyke organic fertilizer treatment had no significant effect on all observed variables. Potassium nitrate treatment and agrodyke organic fertilizer can significantly improve the quality of orange citrus fruit out of season physically. In the treatment of potassium nitrate 40 $\mathrm{g} /$ tree, the weight of the harvested fruit per tree was obtained, the weight per fruit and the highest fruit diameter were $13703.90 \mathrm{~g}$; $99.92 \mathrm{~g}$ and $6.81 \mathrm{~cm}$ or an increase of $62.24 \% ; 16.32 \%$ and $9.49 \%$ compared with no treatment of potassium nitrate which is $8446.60 \mathrm{~g} ; 87,42 \mathrm{~g}$ and $6.22 \mathrm{~cm}$.

e-ISSN: 2550-6986, p-ISSN: 2550-6994@ Copyright 2018. The Author. SS Journals Published by Universidad Técnica de Manabí. This is an open-access article under the CC BY-SA 4.0 license (https://creativecommons.org/licenses/by-sa/4.0/ All rights reserved.

a Agrotechnology Study Program, Faculty of Agriculture, Warmadewa University, Denpasar, Bali, Indonesia

b Agrotechnology Study Program, Faculty of Agriculture, Warmadewa University, Denpasar, Bali, Indonesia

c Agrotechnology Study Program, Faculty of Agriculture, Warmadewa University, Denpasar, Bali, Indonesia

d Agroecotechnology Study Program, Faculty of Agriculture, Udayana University, Denpasar, Bali, Indonesia 


\section{Contents}

Abstract

1. Introduction .

2. Materials and Methods.

3. Results and Discussions

4. Conclusion

Acknowledgements

References

Biography of Authors.

\section{Introduction}

Oranges are the third most important fruit commodity in Indonesia after bananas and mangoes, both from the quantity of production and consumption needs as well as from the value of their trade. Siamese oranges are one of the most cultivated types of oranges and dominate $60 \%$ of the national and regional citrus markets (Dirjenhorti, 2014). In Bali, Siam citrus production centers are in Kintamani District, Bangli Regency, Petang District, Badung Regency, and Payangan District and Tegalalang District, Gianyar Regency.

The constraints faced by the Siamese orange farmers today are that their production is seasonal (not continuous) and the quality of the fruit produced is low. At the time of harvest or often called during the season (on-season) plants produce a lot of fruit, but the quality is low with small sizes so that the selling price is low, instead of many fruits are wasted. When the harvest is frequent, farmers let their citrus fruit expire in the tree (not harvested) because the price is cheap, only reaching Rp. 1,500, - to Rp. 2,000, - / kg (Personal communication with orange farmers in Blancan Village, Kintamani District, Bangli Regency on August 2017). On the contrary outside the harvest or often called during the season (off-season), the plants do not bear fruit so there is no supply and farmers do not get income. This situation in terms of agribusiness is not profitable. Therefore, arrangements are needed so that during the harvest the amount of production is not excessive but the quality of the fruit is prime, while outside the harvest season the plants can produce fruit out of season with good fruit quality.

Low fruit quality at harvest time occurs because farmers allow their crops to bear fruit without being accompanied by good agricultural practices (GAP), especially the lack of balanced fertilization, without pruning leaves and twigs that are protected and attacked by disease and improper harvest time. This caused great competition between fruits in fighting for photosynthate so that the number of fruits harvested a lot but the size was small with low quality. Another impact is that after harvesting the fruit ends up being miserable, weak, and physiologically "sick" because the fruit is loaded with too much fruit but not fertilized and well maintained. According to Srivastava (2009) and Garhwal et al., (2014), citrus plants can produce well when fertilized with organic fertilizers and fertilizers containing N, P, K, and Ca nutrients with the right dosage and application time (Sulistiawati, et al., 2017). Ashraf et al., (2013), Yadav and Ashraf et al., (2013) and Yadav and Solanki (2015) stated that micro fertilizers containing zinc ( $\mathrm{Zn}$ ) and copper (Cu) are also very important given to fruits to improve fruit quality, extend shelf life, and reduce damage during storage.

Continuity of unsustainable fruit supply can be overcome by applying off-season production technology. Out-of-season fruit production is a fertilization arrangement with the aim of getting the fruit in accordance with the desired time, through stretching the fertilization period which is accelerating the beginning of the fruit season or slowing the end of the fruit season. This is done by regulating the start time of flowering in such a way that not all trees bear fruit at the same time so that the balance of supply with the demand for the fruit in question can occur in a longer period of time. Regulating off-season fertilization in absolute terms is to move the fruit harvest season to the extreme for example from January to July or from February to August and vice versa from July to January or August to February. Regulating conception that is more commonly done is the more moderate, namely to promote or reverse fruit harvesting within 1-3 months from the normal fruiting period by advancing or reversing the emergence of flowers with various chemical or mechanical treatments (Poerwanto, 2003). The application of off-season fruit production technology is expected to ensure continuous production volume. This is important because in fruit agribusiness, the fulfillment of the principle of quantity, quality and continuity will have a huge impact in increasing market penetration and Astiari, N. K. A., Kartini, L., Sulistiawati, N. P. A., \& Rai, I. N. (2018). Efforts to produce Siamese citrus fruit out of season and fruit quality improvement through application of potassium nitrate and agrodyke fertilizer. International 
competitiveness. Without engineering, it is very difficult to be able to pick fruit out of season. Naturally, fruits in Indonesia are induced by flowering due to water stress due to a long dry season. With the application of offseason production techniques, dependence on nature can be minimized (Rai and Poerwanto, 2008). It was further stated that the main requirement for the successful application of off-season production technology in fruit plants is that when the flowering induction application of plants must be in good health, vigor and growth are good. These conditions will be obtained from good maintenance through balanced fertilization with inorganic fertilizers and organic fertilizers with the right dose and time. Agrodyke organic fertilizer is a complete type of organic fertilizer containing macro and micronutrients. The composition of nutrient content from agrodyke organic fertilizer is: organic C (18.52\%); C / N ratio (24.16\%); Nitrogen (0.75\%); P205 (2.65\%); K2O (0.85\%); Mo (3.7 ppm); Fe (2694 ppm); Mn (193 ppm); B (129 ppm); Cu (48 ppm) and Zn (25 $\mathrm{ppm})$. The recommended dosage for citrus plants is $100 \mathrm{~g} /$ tree given 3 times a year, by immersing it in the ground, or 1 tablespoon (20 grams of agrodyke) dissolved in 15 liters of water ( 1 tank containing 15 liters of water), giving it sprayed to all plants or wetting through the soil and can reduce the use of inorganic fertilizers $60-70 \%$ (brochure use of agrodyke organic fertilizer, 2015). Mulyani (2010) states that agrodyke can accelerate plant growth and increase soil fertility, can increase plant resistance to pests and diseases, can increase fruit production and quality. Induction (stimulating) flowering so that fruit trees can bear fruit out of season can be done chemically and mechanically (Mehouachi et al., 2008; Wilkie et al., 2008). The principle of the chemical method is to change the physiological processes of plants so that the growth of growth from the vegetative to reproductive phase occurs through the provision of certain compounds such as potassium chlorate $\left(\mathrm{KClO}_{3}\right)$, potassium nitrate $\left(\mathrm{KNO}_{3}\right)$ and Ethepon (Mehouachi et al., 2008). While the principle of the mechanical method is to regulate carbon and nitrogen ratio (C / $\mathrm{N}$ ratio) on shoots by changing the ratio of photosynthetic carbohydrate (C) content and nitrogen content $(\mathrm{N})$ shoots, among others, through pruning, stem twisting (strangulation), ringing, and water stress (Rai et al., 2014). The ability of potassium nitrate in breaking flower bud dormancy according to Mehouachi et al., (2008) is related to the role of K + ions in increasing sucrose translocation, increasing the rate of sucrose transport in apoplast from leaf mesophyll cells, increasing phloem loading and direct effects of increased osmotic pressure. The administration of potassium nitrate with the essential nutrients, namely potassium $(\mathrm{K})$ and nitrogen $(\mathrm{N})$ was reported by Poerwanto et al., (2003) that these substances can be used to stimulate off-season fruit production in mangoes because they are capable of breaking flower bud dormancy. It was also stated that potassium nitrate is a dormancy breaker which is effective in overcoming generative bud dormancy shown by flower buds that have been induced to develop further to produce flowers. Giving it by spraying through the leaves evenly throughout the plant surface at a concentration of $40 \mathrm{~g} / \mathrm{l}$.

\section{Materials and Methods}

His research was carried out in Blancan Village, Kintamani Subdistrict, Bangli Regency which began in October to May 2018. The study used a factorial randomized block design with 2 treatment factors. The first factor is the flower induction application using potassium nitrate $(\mathrm{K})$ consisting of 3 levels, namely $(\mathrm{K} 0=0 \mathrm{~g} /$ tree), $(\mathrm{K} 1=20 \mathrm{~g} /$ tree $)$, and ( $\mathrm{K} 2=40 \mathrm{~g} /$ tree). While the second factor is the application of agrodyke organic fertilizer (P) consisting of 4 levels, namely (P0 $=0 \mathrm{~g} /$ tree), (P1 = $15 \mathrm{~g} /$ tree), (P2 $=30 \mathrm{~g} /$ tree) and (P3 $=45 \mathrm{~g}$ / tree). Thus there are 12 combination treatments and each of them is repeated 3 times so that 36 tree plants are needed.

Citrus plants selected as sample plants in this study were given agrodyke organic fertilizer in advance according to the treatment dose, which was given once in this study by immersing it in the soil, with the aim that the plants grow healthy before they are induced to flower. Trimming branches, twigs and leaves that are protected and attacked by diseases with the aim of reducing assimilate competition between leaves and branches that are not productive with productive ones. Potassium nitrate treatment is given 3 times, first administration 4 weeks after application of agrodyke organic fertilizer. The second and third administration of potassium nitrate is 6 and 8 weeks respectively since the application of agrodyke organic fertilizer. Each treatment of potassium nitrate used is dissolved first into one liter of water then sprayed through the leaves until the plant canopy is evenly affected. 
The variables observed in this study include: number of shots per tree, number of flowers per tree, percentage Fruit-Set per tree, percentage of young fruit deciduous per tree, leaf chlorophyll content, relative water content (KAR) of leaves, $\mathrm{N}$ nutrient content, $\mathrm{P}$ nutrient content and $\mathrm{K}$ nutrient content of leaves, total sugar content of leaves, leaf reduction sugar content and sucrose content of leaves, number of harvested fruits per tree, weight per fruit, fruit diameter and harvest weight per tree. To find out the results and effects of the treatment used, analysis of variance was carried out. Observation data is tabulated to obtain an average value and then analyzed variance. If the treatment has a significant effect, then the BNT test will be carried out.

\section{Results and Discussions}

Based on the results of statistical analysis showed that the interaction between potassium nitrate treatments with agrodyke organic fertilizer (KxP) had no significant effect on all observed variables. Whereas in a single factor, Potassium nitrate $(\mathrm{K})$ treatment showed a real to a very significant effect on all observed variables. Furthermore, the treatment of agrodyke organic fertilizer (P) had a significant until the very significant effect on all observed variables (Table 1). The mean values of the variables observed due to the effect of potassium nitrate treatment and agrodyke organic fertilizer are presented in Table 2 to Table 4. Potassium nitrate treatment of $40 \mathrm{~g} /$ plant gave the highest number of harvested fruits per tree of 145.92 or an increase of $52.6 \%$ when compared to the treatment without potassium nitrate (control) of 95.42 fruits (Table 3). The increase in the number of fruit harvested per tree in the $40 \mathrm{~g} /$ plant potassium nitrate treatment was due to the formation of the number of shoots and the number of flowers per tree was higher, that is 143.59 stalks and 185.58 florets or significantly higher $34.20 \%$ and $33.60 \%$ compared with controls namely 107.00 stalks and 135.17 fruits and significantly different from $20 \mathrm{~g} /$ plant potassium nitrate treatment of 124.33 stalks and 154.92 flowers, also affected by the increase in the number of buds and the number of flowers formed per tree and the development of flowers into fruit so as to increase the percentage of fruit-set (Table 2). In the treatment of $40 \mathrm{~g} /$ plant potassium nitrate obtained fruit-set $107.68 \%$, significantly higher than the control that is $97.67 \%$ (Table 2). The higher percentage of fruit-set compared to controls causes higher fruit yield per tree produced.

Table 1

Significantly of application of potassium nitrate $(\mathrm{K})$ and agrodyke organic fertilizer and its interaction (KxP) with the observed variables

\begin{tabular}{|c|c|c|c|c|}
\hline \multirow[b]{2}{*}{ No. } & \multirow[b]{2}{*}{ Variable } & \multicolumn{3}{|c|}{ Treatment } \\
\hline & & $\begin{array}{l}\text { Potassium } \\
\text { Nitrates } \\
\text { (K) }\end{array}$ & $\begin{array}{l}\text { Agrodyke } \\
\text { Organic } \\
\text { Fertilizer } \\
\text { (P) }\end{array}$ & $\begin{array}{c}\text { Interaction } \\
\text { (КxP) }\end{array}$ \\
\hline 1. & Number of shots per tree (stalk) & $*$ & $* *$ & ns \\
\hline 2. & Number of flowers per tree (florets) & $*$ & $*$ & ns \\
\hline 3. & Percentage Fruit-Set per tree (\%) & * & * & ns \\
\hline 4. & Percentage of young fruit deciduous per tree (\%) & $* *$ & ** & ns \\
\hline 5. & Leaf chlorophyll content (SPAD) & * & $* *$ & ns \\
\hline 6. & Relative water content (KAR) of leaves (\%) & * & * & ns \\
\hline 7. & $\mathrm{~N}$ content in leaves (\%) & ** & * & ns \\
\hline 8. & $\mathrm{P}$ content in leaves (\%) & * & * & ns \\
\hline 9. & K content in leaves $(\%)$ & $* *$ & * & ns \\
\hline 10. & The total sugar content of leaves (\%) & * & * & ns \\
\hline 11. & Leaf Reduction Sugar Content (\%) & * & * & ns \\
\hline 12 & Sucrosa content of leaves (\%) & * & * & ns \\
\hline 13. & Number of fruit harvested per tree $(\mathrm{g})$ & * & * & ns \\
\hline 14. & Weight per fruit (g) & ** & * & ns \\
\hline 15. & The diameter of fruit $(\mathrm{cm})$ & * & * & ns \\
\hline
\end{tabular}

Astiari, N. K. A., Kartini, L., Sulistiawati, N. P. A., \& Rai, I. N. (2018). Efforts to produce Siamese citrus fruit out of season and fruit quality improvement through application of potassium nitrate and agrodyke fertilizer. International Journal of Life Sciences, 2(3), 48-58. https://doi.org/10.29332/ijls.v2n3.206 


\begin{tabular}{ccccc}
\hline 16. & The weight of harvested fruit per tree $(\mathrm{g})$ & $* *$ & $* *$ & ns \\
\hline
\end{tabular}

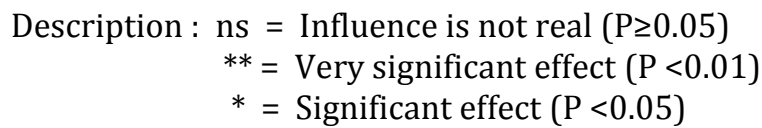

Table 4 shows that harvest weight per tree in $40 \mathrm{~g}$ / plant potassium nitrate treatment is $13703.90 \mathrm{~g}$ which is significantly higher than the control that produces harvest fruit weight per tree which is $8446.60 \mathrm{~g}$ and with $20 \mathrm{~g}$ potassium nitrate treatment, namely $10350.80 \mathrm{~g}$. The higher yield of fruit per tree in potassium nitrate treatment was $40 \mathrm{~g}$ / plant compared to the control, related to the higher number of fruit harvested per tree, fruit diameter and weight per fruit. The number of fruit per tree, fruit diameter and weight per fruit at $40 \mathrm{~g} /$ plant potassium nitrate treatment were 145.92 fruits respectively; $6.81 \mathrm{~cm}$ and $99.92 \mathrm{~g}$ significantly higher than the control, which is $113.08 ; 6.22 \mathrm{~cm}$ and $87.42 \mathrm{~g}$. The number of fruits harvested per tree, fruit diameter and weight per fruit was higher at $40 \mathrm{~g} /$ plant potassium nitrate treatment compared to controls so as to increase the weight of harvested fruit per tree, related to the higher relative water content (KAR) value of the leaves (Table 2). In Table 2 it can be seen that the value of leaf KAR in the treatment of potassium nitrate $40 \mathrm{~g}$ / plant is $188.81 \%$ significantly higher than the control that is $110.17 \%$. The increase in leaf KAR shows that $40 \mathrm{~g} /$ plant potassium nitrate administration increases the ability of plants to absorb water so that the internal water content of plant tissue increases, it is also able to increase nutrient uptake of $\mathrm{N}, \mathrm{P}$ and $\mathrm{K}$. This is shown in Table 3, where the treatment of $40 \mathrm{~g}$ potassium nitrate is / plant, higher nutrient content of N, $\mathrm{P}$ and $\mathrm{K}$, namely $1.71 \%, 0.20 \%$ and $3.98 \%$ compared to controls, namely $1.25 \%, 0.09 \%$ and $2.63 \%$. The increased nutrient content of N, P and K leaves causes metabolic processes to be more guaranteed than controls. This is reflected in the higher chlorophyll content of leaves. The content of leaf chlorophyll in $40 \mathrm{~g} /$ plant potassium nitrate treatment, which is 62.12 SPAD, was significantly higher than that of the control, 50.89 SPAD (Table 2). The higher leaf chlorophyll content in $40 \mathrm{~g} /$ plant potassium nitrate fertilization treatment can make photosynthesis process work well, which is indicated by the higher content of carbohydrate in plants, especially the total sugar content of leaves, reducing sugars and sucrose leaves. In Tables 3 and 4, it can be determined that the total sugar content of leaves, leaf reduction sugars and leaf sucrose were $27.23 \%, 8.90 \%$ and $18.33 \%$, significantly higher than the controls which were $16.07 \%$; $5.93 \%$ and $10.14 \%$. The increase in total sugar content of the leaves as a result of higher leaf chlorophyll content and higher leaf nutrient content in the treatment of potassium nitrate $40 \mathrm{~g}$ / plant was positively correlated with increasing fruit weight per tree, the number of fruit harvested per tree, fruit diameter and weight per fruit compared with control. The data shows that potassium nitrate administration gives hope to be used to increase the production of citrus fruit because it can increase the percentage of fruit-set and increase the amount and weight of fruit per tree.

In the mangosteen plant, Rai (2007) found that the total sugar content of leaves on shoots with real fall flowers was lower than the total leaf sugar on shoots whose flowers did not fall. This shows that the percentage of low fruit-set in Salak Zalacca plants or the fall of flowers in mangosteen plants is related to the low photosynthate supply by the leaves. Rai et al., (2014) reported that the inadequacy of photosynthate supplies caused fruit to fall and this was due to the limited production of assimilates and/or the allocation of assimilates to low fruit. Bonghi et al., (2008) states that assimilation inadequacy does not directly determine the absence of interest because it is also very much determined by the level of competition 
Table 2

Effect of treatment of potassium nitrate and agrodyke organic fertilizer on the average variable number of shots per tree, number of flowers per tree percentage of fruit-set per tree, the percentage of deciduous fruit per tree, leaf chlorophyll content and relative water content (KAR) of leaf

\begin{tabular}{|c|c|c|c|c|c|c|}
\hline Treatment & $\begin{array}{l}\text { Number of } \\
\text { shots per tree } \\
\text { (stalk) }\end{array}$ & $\begin{array}{l}\text { Number of } \\
\text { flowers } \\
\text { per tree } \\
\text { (florets) }\end{array}$ & $\begin{array}{l}\text { Percentage } \\
\text { Fruit-Set per } \\
\text { tree } \\
(\%)\end{array}$ & $\begin{array}{l}\text { Percentage } \\
\text { of deciduous } \\
\text { fruit } \\
\text { per tree } \\
(\%)\end{array}$ & $\begin{array}{c}\text { Leaf } \\
\text { chlorophyll } \\
\text { content } \\
\text { (SPAD) }\end{array}$ & $\begin{array}{c}\text { Relative } \\
\text { water } \\
\text { content } \\
\text { (KAR) } \\
\text { of leaf } \\
(\%)\end{array}$ \\
\hline \multirow{2}{*}{\multicolumn{7}{|c|}{$\begin{array}{l}\text { Potassium } \\
\text { Nitrate } \\
(K)\end{array}$}} \\
\hline & & & & & & \\
\hline $\mathrm{K}_{0}$ & $107,00 \mathrm{~b}$ & $135,17 \mathrm{~b}$ & 97,67 b & $18,70 \mathrm{a}$ & $50,89 \mathrm{~b}$ & $110,17 \mathrm{~b}$ \\
\hline $\mathrm{K}_{1}$ & $124,33 \mathrm{ab}$ & $154,92 \mathrm{ab}$ & $104,09 \mathrm{ab}$ & $14,08 \mathrm{ab}$ & $58,00 \mathrm{ab}$ & $187,24 \mathrm{a}$ \\
\hline $\mathrm{K}_{2}$ & 143,59 a & 185,58 a & 107,68 a & $10,02 \mathrm{~b}$ & $62,12 \mathrm{a}$ & $189,81 \mathrm{a}$ \\
\hline BNT 5\% & 28,59 & 30,20 & 8,10 & 4,64 & 5,29 & 66,16 \\
\hline \multicolumn{7}{|l|}{ Agrodyke } \\
\hline \multicolumn{7}{|l|}{$\begin{array}{c}\text { Fertilizer } \\
(P)\end{array}$} \\
\hline $\mathrm{P}_{0}$ & $98,22 \mathrm{~b}$ & $120,11 \mathrm{c}$ & $96,51 \mathrm{~b}$ & $19,26 \mathrm{a}$ & $55,34 \mathrm{~b}$ & $119,04 \mathrm{~b}$ \\
\hline $\mathrm{P}_{1}$ & $102,11 \mathrm{~b}$ & $150,11 b$ & $103,15 \mathrm{ab}$ & $15,08 \mathrm{~b}$ & $54,72 \mathrm{~b}$ & $124,48 \mathrm{~b}$ \\
\hline $\mathrm{P}_{2}$ & $140,44 \mathrm{a}$ & $181,67 \mathrm{a}$ & $108,71 \mathrm{a}$ & $10,22 \mathrm{c}$ & $63,90 \mathrm{a}$ & $213,51 \mathrm{a}$ \\
\hline $\mathrm{P}_{3}$ & $130,11 \mathrm{a}$ & $175,67 \mathrm{ab}$ & $104,19 \mathrm{ab}$ & $12,50 \mathrm{bc}$ & $59,38 \mathrm{a}$ & $192,59 \mathrm{a}$ \\
\hline BNT 5\% & 27,51 & 28,75 & 7,01 & 4,02 & 4,58 & 57,30 \\
\hline
\end{tabular}

Description: The average value followed by the same letter in the same treatment and column means that it is not significantly different at the $5 \%$ BNT test level

Between "sinks" of fruit or between fruits and shoots and the proximity of the location between "sink" and "source". The total sugar content in higher leaves can reduce fruit loss. The lowest percentage of deciduous fruit at $40 \mathrm{~g} /$ plant potassium nitrate treatment was only $10.02 \%$ compared to the control of $18.70 \%$ (Table 2). So the quality of the fruit produced because of the higher weight per fruit will be valued by consumers more expensive. The treatment of $30 \mathrm{~g}$ of agrodyke organic fertilizer/plant gave the highest number of harvested fruit per tree, which was 136.67 or an increase of $54.53 \%$ when compared to the treatment without agrodyke organic fertilizer (control), which was 88.44 fruits (Table 3). The increase in the number of fruit harvested per tree in the treatment of $30 \mathrm{~g}$ of agrodyke organic fertilizer/plant was due to the formation of the number of shoots and the number of flowers per tree was higher, namely 140.44 stalks and 181,67 florets or significantly higher $42.99 \%$ and $51.25 \%$ compared with the control that is only 98.22 stalks and 120.11 fruits and significantly different from the treatment of $15 \mathrm{~g}$ of agrodyke organic fertilizer / plant which is 102.11 stalks and 150.11 stems (Table 2). The increase in the number of fruit harvested per tree in the treatment of $30 \mathrm{~g}$ of agrodyke organic fertilizer/plant besides being influenced by the increasing number of buds and the number of flowers formed per tree is also affected by the development of the flower into fruit so as to increase the percentage of fruit-set. In the treatment of $30 \mathrm{~g}$ of agrodyke organic fertilizer/plant, fruit-set of $108.71 \%$ was obtained, significantly higher than the control of $96.51 \%$. The higher percentage of fruit-set compared to controls caused higher yield of fruit per tree produced (Table 4). In Table 4 shows that the weight of harvested fruit per tree in the treatment of $30 \mathrm{~g} /$ plant agrodyke organic fertilizer is $12900.28 \mathrm{~g}$ is significantly higher than the control that produces harvest fruit weight per tree that is $7892.69 \mathrm{~g}$ and with the treatment of agrodyke organic fertilizer $15 \mathrm{~g} /$ plant is $9803.32 \mathrm{~g}$. The higher weight of harvested fruit per tree in the treatment of agrodyke organic fertilizer $30 \mathrm{~g} /$ plant compared to the control, related to the higher number of fruit harvested per tree, fruit diameter and weight per fruit. The number of fruit per tree, fruit diameter and weight per fruit in the treatment of $30 \mathrm{~g} /$ plant of agrodyke organic fertilizer were 136.67

Astiari, N. K. A., Kartini, L., Sulistiawati, N. P. A., \& Rai, I. N. (2018). Efforts to produce Siamese citrus fruit out of season and fruit quality improvement through application of potassium nitrate and agrodyke fertilizer. International Journal of Life Sciences, 2(3), 48-58. https://doi.org/10.29332/ijls.v2n3.206 
fruits; $6.94 \mathrm{~cm}$ and $101.14 \mathrm{~g}$ significantly higher than the control, which is 88.44 pieces; $6.30 \mathrm{~cm}$ and $88.90 \mathrm{~g}$ (Table 4).

Table 3

Effect of treatment of potassium nitrate and agrodyke organic fertilizer on the average variable of nutrient content $\mathrm{N}$ leaves, nutrient content $\mathrm{P}$ leaves, nutrient content $\mathrm{K}$ leaves, the total sugar content of leaves and reducing the sugar content of leave

\begin{tabular}{cccccc}
\hline Treatment & $\begin{array}{c}\text { N content } \\
\text { in leaves } \\
(\%)\end{array}$ & $\begin{array}{c}\text { P content } \\
\text { in leaves (\%) }\end{array}$ & $\begin{array}{c}\text { K content } \\
\text { in leaves } \\
(\%)\end{array}$ & $\begin{array}{c}\text { Total sugar } \\
\text { content of } \\
\text { leaves } \\
(\%)\end{array}$ & $\begin{array}{c}\text { Leaf Reduction } \\
\text { Sugar Content } \\
(\%)\end{array}$ \\
\hline $\begin{array}{c}\text { Potassium Nitrate } \\
\text { (K) }\end{array}$ & & & & \\
$\mathrm{K}_{0}$ & $1,25 \mathrm{~b}$ & $0,09 \mathrm{c}$ & $2,63 \mathrm{~b}$ & $16,07 \mathrm{a}$ & $5,93 \mathrm{c}$ \\
$\mathrm{K}_{1}$ & $1,55 \mathrm{a}$ & $0,16 \mathrm{~b}$ & $2,99 \mathrm{a}$ & $21,31 \mathrm{~b}$ & $7,63 \mathrm{~b}$ \\
$\mathrm{~K}_{2}$ & $1,71 \mathrm{a}$ & $0,20 \mathrm{a}$ & $3,98 \mathrm{a}$ & $27,23 \mathrm{c}$ & $8,90 \mathrm{a}$ \\
BNT 5\% & 0,21 & 0,03 & 0,34 & 1,94 & 0,44 \\
Agrodyke & & & & & \\
Fertilizer & & & & & \\
$(P)$ & $1,29 \mathrm{~b}$ & $0,07 \mathrm{c}$ & $2,34 \mathrm{~b}$ & $18,71 \mathrm{c}$ & $6,88 \mathrm{c}$ \\
$\mathrm{P}_{0}$ & $1,57 \mathrm{a}$ & $0,14 \mathrm{~b}$ & $2,80 \mathrm{a}$ & $21,87 \mathrm{~b}$ & $7,83 \mathrm{~b}$ \\
$\mathrm{P}_{1}$ & $1,70 \mathrm{a}$ & $0,19 \mathrm{a}$ & $2,96 \mathrm{a}$ & $25,10 \mathrm{a}$ & $9,23 \mathrm{a}$ \\
$\mathrm{P}_{2}$ & $1,69 \mathrm{a}$ & $0,17 \mathrm{a}$ & $2,54 \mathrm{a}$ & $24,68 \mathrm{a}$ & $9,21 \mathrm{a}$ \\
$\mathrm{P}_{3}$ & 0,21 & 0,03 & 0,34 & 1,94 & 0,44 \\
\hline BNT 5\% & & & & & \\
\hline
\end{tabular}

Description: The average value followed by the same letter in the same treatment and column means that it is not significantly different at the $5 \%$ BNT test level

Mulyani (2010) states that agrodyke organic fertilizer can accelerate plant growth and increase soil fertility, can increase plant resistance to pests and diseases, can increase fruit production and quality. Agrodyke organic fertilizer besides containing nutrients $\mathrm{N}, \mathrm{P}, \mathrm{K}, \mathrm{Mo}, \mathrm{Fe}, \mathrm{Mn}, \mathrm{B}, \mathrm{Cu}$ and $\mathrm{Zn}$, the high organic $\mathrm{C}$ content contained in it can cause the soil to become fertile, the development of citrus roots is good so the root function in absorbing water and nutrients can be increased which can later support increased above-ground growth so that it can support photosynthesis activities more optimally. By increasing the number of shoots and the number of flowers formed higher, it was also supported by higher relative water content (KAR) of leaves and leaf chlorophyll content in the treatment of $30 \mathrm{~g} /$ plant agrodyke organic fertilizer, namely $213.51 \%$, and 33.90 SPAD respectively. The increase in leaf KAR and leaf chlorophyll in the administration of $30 \mathrm{~g} / \mathrm{plant}$ of agrodyke organic fertilizer was also followed by an increase in nutrient content of $\mathrm{N}$ leaves $(1.70 \%)$, nutrient content of P leaves $(0.19 \%)$ and content of $\mathrm{K}$ leaves $(2.96 \%)$, compared with control plants, which are $1.29 \%$ $\mathrm{N}$ respectively; $0.07 \% \mathrm{P}$ and $2.34 \% \mathrm{~K}$ leaves (Tables 2 and 3). This shows that the administration of agrodyke organic fertilizer can improve the water status of plant tissues, which is shown by the increase in the relative water content (KAR) of leaves. These conditions cause better metabolic processes of plants that can increase leaf chlorophyll content, which causes photosynthetic activity to be more optimal as evidenced by higher total sugar content, reduced sugar and sucrose leaves (Tables 3 and 4). In Tables 3 and 4 it can be seen that the total sugar content, reducing sugar and sucrose leaves on plants given $30 \mathrm{~g} /$ plant of agrodyke organic fertilizer was $25.10 \% ; 9.23 \%$ and $15.87 \%$ are significantly higher compared to plants that were not given agrodyke organic fertilizer, namely $18.71 \% ; 6.88 \%$ and $10.83 \%$. Low photosynthate received by flowers in citrus plants that are not given agrodyke organic fertilizer associated with higher competition in competing for photosynthesis between fruits that are formed, so that physiologically reduce the ability of flowers or fruit to obtain photosynthates. 
Table 4

Effect of treatment of potassium nitrate and agrodyke organic fertilizer on average variable sucrose content of leaves, number of fruit harvested per tree, weight per fruit, the diameter of fruit and weight of harvested fruit per tree

\begin{tabular}{cccccc}
\hline Treatment & $\begin{array}{c}\text { Sucrose } \\
\text { content of } \\
\text { leaves } \\
(\%)\end{array}$ & $\begin{array}{c}\text { Number } \\
\text { of fruit harvested } \\
\text { per tree } \\
(\mathrm{g})\end{array}$ & $\begin{array}{c}\text { Weight } \\
\text { per } \\
\text { fruit } \\
(\mathrm{g})\end{array}$ & $\begin{array}{c}\text { Diameter } \\
\text { of fruit } \\
(\mathrm{cm})\end{array}$ & $\begin{array}{c}\text { The weight of } \\
\text { harvested fruit per } \\
\text { tree } \\
(\mathrm{g})\end{array}$ \\
\hline $\begin{array}{c}\text { Potassium } \\
\text { Nitrate }\end{array}$ & & & & \\
$($ K) & & & & & \\
$\mathrm{K}_{0}$ & $10,14 \mathrm{c}$ & $95,42 \mathrm{~b}$ & $80,42 \mathrm{~b}$ & $6,22 \mathrm{~b}$ & $8446,60 \mathrm{~b}$ \\
$\mathrm{~K}_{1}$ & $13,68 \mathrm{~b}$ & $113,08 \mathrm{~b}$ & $99,56 \mathrm{ab}$ & $6,64 \mathrm{ab}$ & $10350,80 \mathrm{a}$ \\
$\mathrm{K}_{2}$ & $18,33 \mathrm{a}$ & $145,92 \mathrm{a}$ & $99,92 \mathrm{a}$ & $6,81 \mathrm{a}$ & $13703,90 \mathrm{a}$ \\
BNT 5\% & 1,64 & 24,95 & 8,99 & 0,46 & 2630,63 \\
Agrodyke Fertilizer & & & & & \\
$(P)$ & & & & & \\
$\mathrm{P}_{0}$ & $10,83 \mathrm{c}$ & $88,44 \mathrm{~b}$ & $85,90 \mathrm{~b}$ & $6,30 \mathrm{~b}$ & $7892,69 \mathrm{~b}$ \\
$\mathrm{P}_{1}$ & $14,04 \mathrm{~b}$ & $105,67 \mathrm{ab}$ & $92,34 \mathrm{~b}$ & $6,56 \mathrm{~b}$ & $9803,32 \mathrm{~b}$ \\
$\mathrm{P}_{2}$ & $15,87 \mathrm{a}$ & $136,67 \mathrm{a}$ & $101,14 \mathrm{a}$ & $6,94 \mathrm{a}$ & $12900,28 \mathrm{a}$ \\
$\mathrm{P}_{3}$ & $15,47 \mathrm{a}$ & $125,11 \mathrm{a}$ & $100,38 \mathrm{a}$ & $6,44 \mathrm{~b}$ & $12738,86 \mathrm{a}$ \\
BNT 5\% & 1,64 & 21,61 & 21,61 & 0,40 & 2278,19 \\
\hline
\end{tabular}

Description: The average value followed by the same letter in the same treatment and column means that it is not significantly different at the 5\% BNT test level

Rai et al., (2014) reported that the insufficiency of photosynthate supplies caused fruit to fall, and that this was caused by limited photosynthetic production and/or photosynthate allocation to low fruit. in citrus plants that are not given agrodyke organic fertilizer associated with higher competition in competing for photosynthesis between fruits that are formed, so that physiologically reduce the ability of flowers or fruit to obtain photosynthates. Rai et al., (2014) reported that the insufficiency of photosynthate supplies caused fruit to fall and that this was caused by limited photosynthetic production and/or photosynthate allocation to low fruit. In control plants (not given agrodyke organic fertilizer), the percentage of deciduous young fruit was more than $19.26 \%$ and in plants given agrodyke organic fertilizer $15 \mathrm{~g} /$ plant the percentage of deciduous young fruit was $15.08 \%$ significantly higher than that of plants given Agrodyke organic fertilizer $30 \mathrm{~g} /$ plant, which is only $7.68 \%$ (Table 2).

\section{Conclusion}

From the results of this study, it can be concluded that:

a) The interaction between potassium nitrate treatment and agrodyke organic fertilizer has no significant effect on all observed variables.

b) Potassium-nitrate treatment can significantly improve the quality of orange citrus fruit outside the season physically. The treatment of potassium nitrate at $40 \mathrm{~g} /$ plant yields the weight of the fruit per tree, the weight per fruit and the highest fruit diameter is $13703.90 \mathrm{~g}$ respectively; $99.92 \mathrm{~g}$ and $6.81 \mathrm{~cm}$ or $62.24 \%$ increase; $16.32 \%$ and $9.49 \%$ compared with no potassium nitrate treatment ie $8446.60 \mathrm{~g}$; $87,42 \mathrm{~g}$ and $6.22 \mathrm{~cm}$.

c) The treatment of agrodyke organic fertilizer can significantly improve the quality of citrus fruit physically, which can be demonstrated by giving agrodyke organic fertilizer $30 \mathrm{~g} /$ plant giving the highest yield of fruit per tree, the highest weight per fruit and $12900.28 \mathrm{~g} ; 101.14 \mathrm{~g}$ and $6.94 \mathrm{~cm}$ or an

Astiari, N. K. A., Kartini, L., Sulistiawati, N. P. A., \& Rai, I. N. (2018). Efforts to produce Siamese citrus fruit out of season and fruit quality improvement through application of potassium nitrate and agrodyke fertilizer. International Journal of Life Sciences, 2(3), 48-58. https://doi.org/10.29332/ijls.v2n3.206 
increase of $63.44 \% ; 25.02 \%$ and $10.16 \%$ compared to without agrodyke organic fertilizer which is only $7892.69 \mathrm{~g} ; 80.90 \mathrm{~g}$ and $6.30 \mathrm{~cm}$.

Acknowledgments

Thank you to LEMLIT Warmadewa University for funding the Higher Education Applied Research (PTUPT) provided through the 2018 Institution Grant. 


\section{References}

Ashraf, M. Y., Ashraf, M., Akhtar, M., Mahmood, K., \& Saleem, M. U. H. A. M. M. A. D. (2013). Improvement in yield, quality and reduction in fruit drop in kinnow (Citrus reticulata blanco) by exogenous application of plant Growth regulators, potassium and zinc. Pak. J. Bot, 45(S1), 433-440.

Bonghi, C., Tonutti, P., \& Ramina, A. (2000). Biochemical and molecular aspects of fruitlet abscission. Plant Growth Regulation, 31(1-2), 35-42.

Dirjenhorti (Direktortat Jenderal Hortikultura). 2014. Volume dan Nilai Ekspor-Impor Hortikultura Indonesia Periode 2009-2013. Departemen Pertanian, Jakarta.

Garhwal, P. C., Yadav, P. K., Sharma, B. D., Singh, R. S., \& Ramniw, A. S. (2014). Effect of organic manure and nitrogen on growth yield and quality of kinnow mandarin in sandy soils of hot arid region. African Journal of Agricultural Research, 9(34), 2638-2647.

Mehouachi, J., Tadeo, F. R., Zaragoza, S., Primo-Millo, E., \& Talon, M. (1996). Effects of gibberellic acid and paclobutrazol on growth and carbohydrate accumulation in shoots and roots of citrus rootstock seedlings. Journal of Horticultural Science, 71(5), 747-754.

Mulyani, S. (2010). Pupuk dan Cara Pemupukan. Rineka Cipta, Jakarta.

Poerwanto, R. (2003). Peran manajemen budidaya tanaman dalam peningkatan ketersediaan dan mutu buahbuahan. Orasi Ilmiah Guru Besar Tetap Ilmu Hortikultura, Agricultural Department, Bogor Agricultural University. Bogor.

Poerwanto, R., Efendi, D., \& Harjadi, S. S. A. (1997). Pengaturan pembungaan mangga Gadung 21 di luar musim dengan paklobutrazol dan zat pemecah dormansi.

Rai, I. N. (2007). Bunga dan buah gugur pada tanaman manggis (Garcinia mangostana L.) asal biji dan sambungan. Agritrop, 26(2), 66-73.

Rai, I. N., \& Poerwanto, R. (2008). Memproduksi Buah Di Luar Musim. Pernerbit: Andi, Yogyakarta.

Rai, I. N., Wiraatmaja, I. W., Semarajaya, C. G. A., \& Astiari, N. K. A. (2014). Application of drip irrigation technology for producing fruit of Salak "Gula Pasir"(Salacca zalacca var. Gulapasir) off season on dry land. Journal of Degraded and Mining Lands Management, 2(1), 219-222.

Srivastava, A. K. (2009). Integrated nutrient management: Concept and application in citrus. Citrus II. Tree For Sci Biotechnol, 3, 32-58.

Sulistiawati, N. P. A., Kartini, L., \& Yuliartini, M. S. (2017). Identification of Development Phases and Changes Shoots Flowering Orange Siam Plants. International Journal of Life Sciences (IJLS), 1(2), 28-38.

Wilkie, J. D., Sedgley, M., \& Olesen, T. (2008). Regulation of floral initiation in horticultural trees. Journal of experimental botany, 59(12), 3215-3228.

Yadav, M. K., \& Solanki, V. K. (2015). Use of micronutrients in tropical and sub-tropical fruit crops: A review. African Journal of Agricultural Research, 10(5), 416-422.

Yadav, S. K., Gupta, V., El Kohly, A., \& Al Fadhli, W. (2013). Perforated duodenal ulcer: a rare complication of deferasirox in children. Indian journal of pharmacology, 45(3), 293.

Astiari, N. K. A., Kartini, L., Sulistiawati, N. P. A., \& Rai, I. N. (2018). Efforts to produce Siamese citrus fruit out of season and fruit quality improvement through application of potassium nitrate and agrodyke fertilizer. International Journal of Life Sciences, 2(3), 48-58. https://doi.org/10.29332/ijls.v2n3.206 


\section{Biography of Authors}

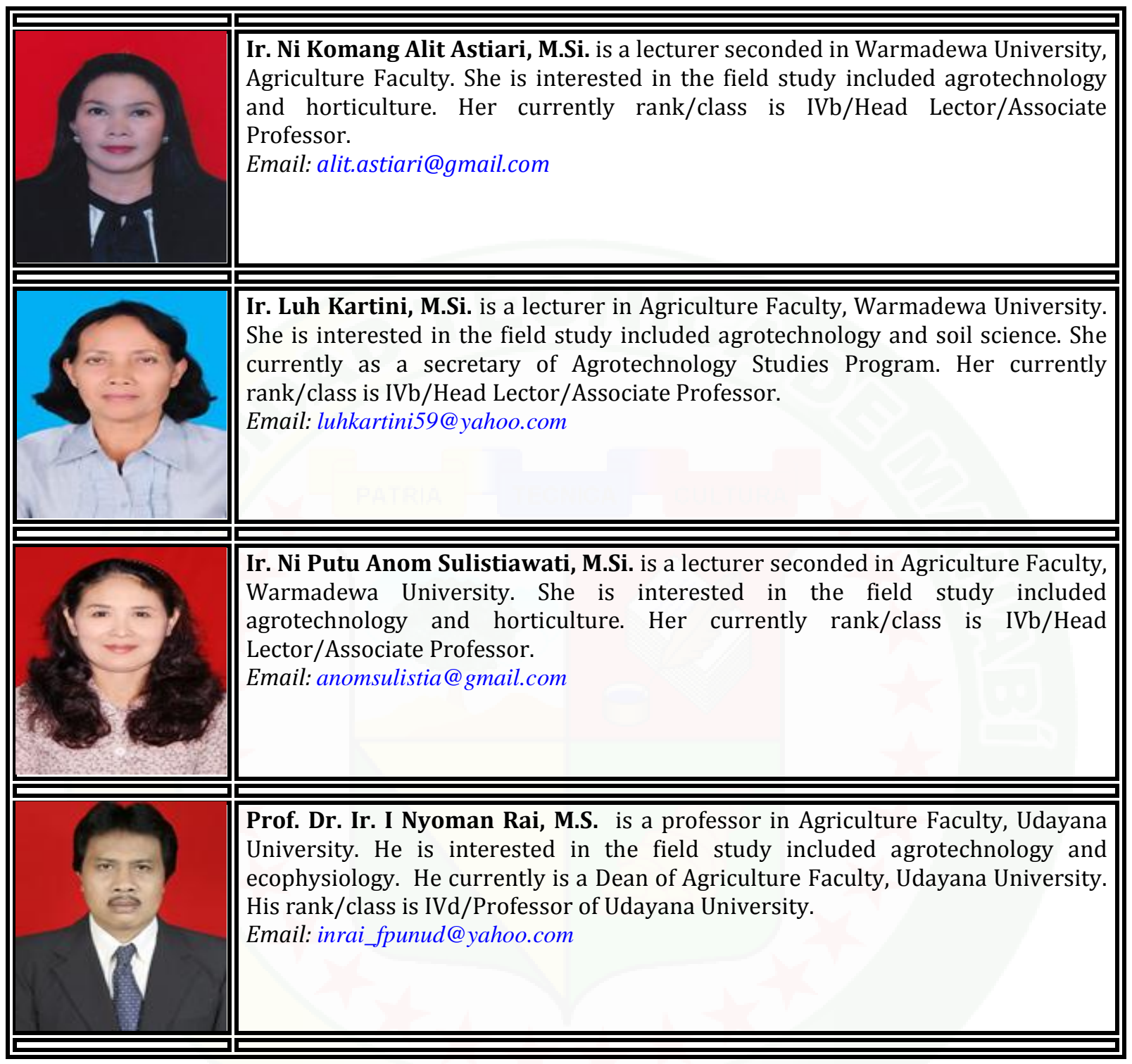

